\title{
TENDENCE SPREMINJANJA PODNEBJA PO 2. SVETOVNI VOJNI NA JUGOVZHODU KRASA
}

\author{
dr. Darko Ogrin
}

Oddelek za geografijo, Filozofska fakulteta Univerze v Ljubljani

Aškerčeva 2, SI-I000 Ljubljana

e-mail: darko.ogrin@ff.uni-lj.si

Izvirni znanstveni članek

COBISS 1.01

DOI: 10.4312/dela.41.4.81-100

\section{Izvleček}

Prispevek obravnava trende spreminjanja temperature zraka in padavin v višjem, jugovzhodnem delu Krasa. Zaledno zmerno sredozemsko podnebje se tu prepleta s celinskim podnebjem, zato se značilnosti spreminjanja podnebja nekoliko razlikujejo od trendov ob obali Tržaškega zaliva. Zaradi manjšega vpliva morja je trend segrevanja ozračja izrazitejši, še posebej spomladi in poleti, bolj izrazito kot ob morju je tudi zmanjševanje letne vsote padavin.

Ključne besede: spreminjanje podnebja, podnebje v instrumentalnem obdobju, zmerno sredozemsko podnebje, Kras, Slovenija

\section{CLIMATE CHANGE TENDENCIES AFTER THE SECOND WORLD WAR IN THE SOUTHEASTERN KRAS}

\begin{abstract}
The paper discusses trends in the changing of air temperatures and precipitation in the higher, southeastern part of the Kras. The sub-Mediterranean climate of the hinterland is here combined with continental climate, therefore, the characteristics of climate changes slightly differ from the trends along the shore of the Gulf of Trieste. Due to the lesser impact of the sea, the air warming trend is more explicit, especially in spring and summer. More explicit than by the sea is also the decline in annual precipitation amount.
\end{abstract}

Key words: climate change, climate in instrumental period, sub-Mediterranean climate, Kras (Karst), Slovenia 


\section{UVOD}

Spreminjanje podnebja v obsredozemskem delu Slovenije v instrumentalnem obdobju je dobro raziskano za obalni del (Ogrin, D., 1994; 1995). Zaradi nehomogenih podatkov, kot posledice pogostih selitev in ukinjanja postaj (več o tem v Ogrin, D., 1995; 2000), je v raziskave kot reprezentant slovenskega obalnega pasu pogosto vključena tudi meteorološka postaja v Trstu (Ogrin, D., 2003; 2012). Za predele z zalednim zmerno sredozemskim podnebjem je raziskav manj. Več je znanega o podnebnih trendih v nižje ležečih severozahodnejših pokrajinah s tem podnebjem, kjer je zaradi kakovostnih podatkovnih nizov pogosto analizirana meteorološka postaja Bilje (n. v. 55 m) (npr. Bergant, 2007; Bertalanič in sod., 2010; Kajfež Bogataj in sod., 2010). Ugotovljeni trendi za Bilje so zaradi nižje nadmorske višine in večje odprtosti proti Tržaškemu zalivu zelo sorodni trendom ob morju. Za višje, jugovzhodnejše predele z zmerno sredozemskim podnebjem, kjer se kot podnebna modifikatorja izraziteje uveljavljata nadmorska višina in celinskost, podrobnejših raziskav ni.

Zaradi domneve, da se trendi spreminjanja podnebja v višje ležečih predelih Slovenije z zalednim zmerno sredozemskim podnebjem v nekaterih elementih razlikujejo od trendov ob morju, smo raziskavo usmerili na jugovzhodni del Krasa med Dutovljami in Škocjanskimi jamami. Jugovzhodni del Krasa je bil v zadnjih desetletjih v geografski in sorodni literaturi obravnavan predvsem z različnih krasoslovnih vidikov (npr. Gams, 1998; Mihevc, 1995; 1996; 2001; Stepišnik in sod., 2007), precej del se nanaša na Škocjanske in druge jame (npr. Gams, Kogovšek, 1998; Stepišnik in sod., 2009; Mihevc, Stepišnik, 2011; Beltram in sod., 2012). Prispevka Mrakove in Repeta (2000; 2004) se ukvarjata s fizičnogeografskimi pogoji za uspevanje vinske trte. Obravnavo podnebnih razmer smo zasledili le v večjezičnih predstavitvah Parka Škocjanske jame (npr. Mihevc, 2002).

Jugovzhodni del Krasa leži v nadmorskih višinah med 300 m v okolici Dutovelj do okoli 450 m v okolici Škocjanskih jam. Nad planoto, ki visi proti severozahodu, se dvigajo posamezne vzpetine z nadmorsko višino 600 do $700 \mathrm{~m}$. S podnebnega vidika je pomemben niz vzpetin vzdolž slovensko-italijanske meje (Volnik, $546 \mathrm{~m}$; V. Medvedjak, 472 m; Goli vrh, 476 m; Kokoš, 674 m; V. Gradišče, 741 m), ki ta del Krasa skupaj z Brkini in Slavnikom zapira proti morju (slika 1).

Zaledno zmerno sredozemsko podnebje (Ogrin, D., 1996; Ogrin, D., Plut, 2009), ki zavzema jugozahodni del Slovenije pod alpsko-dinarsko pregrado, razen obalnega pasu Slovenske Istre, nižje ležečih severozahodnih delov Krasa, Goriškega polja in nižjih delov Goriških brd, se od obalnega zmerno sredozemskega podnebja razlikuje predvsem po nekoliko nižjih temperaturah in več padavinah. Povprečna temperatura najhladnejšega meseca je med 0 in $4{ }^{\circ} \mathrm{C}$ (ob obali nad $4{ }^{\circ} \mathrm{C}$ ), najtoplejšega pa med 20 in $22^{\circ} \mathrm{C}$ (ob obali $\operatorname{nad} 22^{\circ} \mathrm{C}$ ). Letna vsota padavin je med 1300 in $1700 \mathrm{~mm}$ (ob obali do $1300 \mathrm{~mm}$ ) in narašča v smeri dinarske pregrade. Višek padavin je v jeseni. Zaradi večje oblačnosti je v zaledju Tržaškega zaliva nekoliko manj Sončevega sevanja kot ob obali, jakost vetra pa je na račun burje večja. 
V začetnem delu prispevka je opisan pregled razvoja meteoroloških postaj v širšem območju obravnavane pokrajine in z njim povezana kakovost podatkov z vidika analize časovnih vrst. V nadaljevanju so predstavljeni trendi spreminjanja sezonskih in letnih temperatur ter padavin za meteorološki postaji Godnje pri Tomaju (temperatura zraka) in Matavun (padavine) po letu 1951 ter tendence spreminjanja podnebja $\mathrm{v}$ zadnjih dveh desetletjih v primerjavi s standardnim klimatološkim obdobjem 1961-1990. Statistična obdelava podatkov je bila narejena s pomočjo programskega paketa Excel for Windows.

Slika 1: Reliefna podoba in meteorološke postaje na jugovzhodnem delu Krasa Figure 1: Landform appearance and meteorological stations in the southeastern Kras

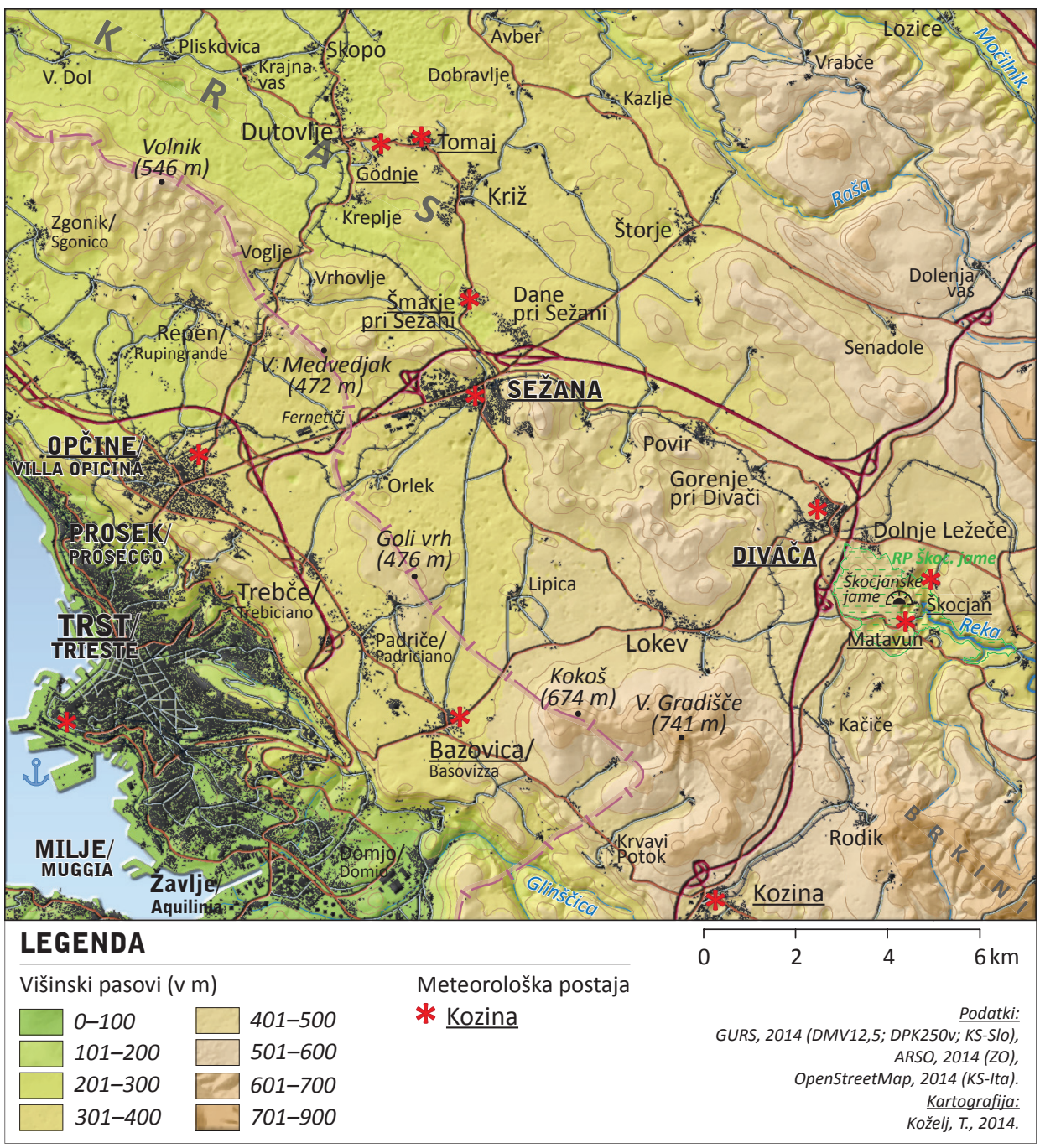




\section{RAZVOJ MREŽE METEOROLOŠKIH POSTAJ IN PODATKOVNI NIZI}

Osnovni problem pri analizi dolgoletnih nizov podnebnih podatkov ter ugotavljanja spremenljivosti in trendov podnebja je njihova dolžina in homogenost. Za zanesljive rezultate bi morale meteorološke postaje ustrezati kriterijem za referenčne postaje, t. j. imeti nespremenjen način in postopek opazovanja ter meritev, ohranjati isti tip merilnih inštrumentov in stalno delovati na istem mestu $\mathrm{z}$ nespremenjeno okolico. Tem pogojem se v Sloveniji približuje le nekaj meteoroloških postaj, med njimi še najbolj Rateče. V nasprotnem bi morali imeti kvalitetne podatke o pogojih meritev v posameznih obdobjih (metapodatke), s katerimi lahko korigiramo meritve in homogeniziramo nize, oziroma lažje ovrednotimo dobljene rezultate.

V širši okolici obravnavanega območja ima najdaljši in kvaliteten niz podatkov meteorološka postaja v Trstu. Ta se je v svoji dolgi zgodovini sicer večkrat selila, vendar vedno znotraj strnjeno pozidanega dela mesta. Ima tudi dobro dokumentacijo o pogojih meritev v posameznih obdobjih, ki je omogočila homogenizacijo podatkov. Po zapisu Scusse v Tržaški kroniki (cv: Stravisi, 1976) so se v Trstu pričela redna »termometrična, barometrična in meteorološka opazovanja« leta 1779, vendar so se podatki iz tega časa izgubili. Na pobudo Cesarsko-kraljeve akademije za trgovino in pomorstvo (L'Imperiale Reggia Accademia di Commercio e Nautica di Trieste) so se v Trstu redna, nepretrgana vizualna in instrumentalna meteorološka opazovanja, ki še trajajo, ponovno začela s 1 . januarjem 1841.

Ob koncu 19. in v začetku 20. st. je bilo ustanovljenih nekaj meteoroloških postaj tudi na jugovzhodnem Krasu. Večinoma so bile to padavinske postaje ali padavinske postaje s totalizatorji, ki so delovale bolj ali manj redno. Po Pučniku (1980) so leta 1894 ustanovili postajo v Bazovici in na Opčinah na Tržaškem krasu, 1895 v Senožečah, 1896 v Sežani in Komnu, 1897 v Divači in leta 1910 v Tomaju. Podatki za te postaje so objavljeni v različnih publikacijah (Biel, 1927; Mazelle, 1908; Benussi, 1903). Zaradi številnih podatkov izpostavljamo delo E. Biela (1927) Klimatographie des ehemaligen österreichischen Küstenlandes. Podatke iz tega dela, kjer so nekateri tudi interpolirani na daljša obdobja, je za prilogo k svoji knjigi povzel tudi Pučnik (1980). Zanimivejši podatki za obravnavano območje so v preglednicah 1 in 2 .

Preglednica 1: Povprečna mesečna in letna temperatura zraka $\left(v^{\circ} \mathrm{C}\right)$ za Opčine (n. v. $\left.320 \mathrm{~m}\right)$, Bazovico (n. v. 372 m) in Divačo (n. v. 432 m) v obdobju 1870-1914

Table 1: Average monthly and annual air temperatures $\left(\right.$ in $\left.{ }^{\circ} \mathrm{C}\right)$ at Opčine/Villa Opicina (320 m), Basovizza/Bazovica (372 m) and Divača (432 m) in the 1870-1914 period

\begin{tabular}{|l|r|c|c|c|c|c|c|c|c|c|c|c|c|}
\cline { 2 - 13 } \multicolumn{1}{c|}{} & Jan. & Feb. & Mar. & Apr. & Maj & Jun. & Jul. & Avg. & Sep. & Okt. & Nov. & Dec. & Leto \\
\hline Opčine & 1,4 & 2,6 & 6,1 & 10,4 & 14,9 & 18,8 & 21,5 & 20,5 & 16,6 & 11,4 & 6,5 & 3,1 & 11,2 \\
\hline Bazovica & 1,6 & 2,6 & 6,0 & 9,7 & 14,5 & 18,5 & 21,3 & 20,4 & 16,6 & 11,8 & 6,7 & 3,4 & 11,1 \\
\hline Divača & 0,5 & 1,6 & 5,5 & 9,8 & 14,0 & 17,7 & 20,1 & 19,4 & 15,2 & 10,7 & 5,5 & 2,0 & 10,2 \\
\hline
\end{tabular}

Vir/Source: Pučnik, 1980, str. 285 
Preglednica 2: Povprečna mesečna in letna višina padavin (v mm) za Komen (n. v. $286 \mathrm{~m}$ ) in Divačo (n. v. 432 m) v obdobju 1890-1914

Table 2: Average monthly and annual precipitation (in $\mathrm{mm}$ ) at Komen (286 $\mathrm{m}$ ) and Divača (432 $\mathrm{m}$ ) in the 1890-1914 period

\begin{tabular}{|l|r|r|r|r|r|r|r|r|r|r|r|r|r|}
\cline { 2 - 14 } \multicolumn{1}{c|}{} & Jan. & Feb. & Mar. & Apr. & Maj & Jun. & Jul. & Avg. & Sep. & Okt. & Nov. & Dec. & Leto \\
\hline Komen & 72 & 73 & 112 & 100 & 137 & 129 & 119 & 101 & 128 & 161 & 134 & 124 & 1386 \\
\hline Divača & 56 & 67 & 103 & 109 & 113 & 154 & 121 & 128 & 120 & 144 & 120 & 161 & 1347 \\
\hline
\end{tabular}

Vir/Source: Pučnik, 1980, str. 286

Po koncu 1. svetovne vojne so prešle pod upravo centralnih italijanskih meteoroloških in hidroloških oblasti tudi nekatere meteorološke opazovalnice, ustanovljene v času Avstro-Ogrske, kolikor niso medtem že prenehale delovati. Italijanske oblasti so delovanje nekaterih ponovno oživile, nekatere so nastale na novo. Dejstvo je, da je Kras za obdobje med obema svetovnima vojnama zelo dobro pokrit s podatki, zlasti s padavinskimi, bistveno bolje, kakor npr. v zadnjih desetih letih. Najbolj dostopen vir podatkov za to obdobje so Prilozi poznavanja klime Jugoslavije (1957), ki jih je izdala hidrometeorološka služba tedanje Jugoslavije, v katerem so za obdobje 1925-1940 zbrani podatki o padavinah. Kot dopolnilni vir, predvsem padavinskih podatkov, lahko uporabimo tudi tabelarično prilogo v zborniku Krš Slovenije (1957; preglednica 3).

Preglednica 3: Povprečna mesečna in letna višina padavin (v mm) za širše območje jugovzhodnega Krasa v obdobju 1925-1940

Table 3: Average monthly and annual precipitation (in $\mathrm{mm}$ ) in a broader area of the southeastern Kras in the 1925-1940 period

\begin{tabular}{|l|r|r|r|r|r|r|r|r|r|r|r|r|r|}
\cline { 2 - 16 } \multicolumn{1}{c|}{} & Jan. & Feb. & Mar. & Apr. & Maj & Jun. & Jul. & Avg. & Sep. & Okt. & Nov. & Dec. & Leto \\
\hline Škocjan & 89 & 62 & 111 & 96 & 148 & 124 & 90 & 110 & 162 & 158 & 161 & 94 & 1405 \\
\hline Il. Bistrica & 82 & 61 & 111 & 101 & 127 & 114 & 91 & 108 & 133 & 150 & 174 & 103 & 1355 \\
\hline Bazovica & 89 & 45 & 112 & 91 & 113 & 101 & 71 & 89 & 123 & 148 & 143 & 84 & 1209 \\
\hline Opčine & 87 & 55 & 119 & 93 & 145 & 115 & 83 & 97 & 167 & 183 & 183 & 101 & 1428 \\
\hline
\end{tabular}

Vir/Source: Krš Slovenije, 1957, str. 22-24

Obdobje po 2 . svetovni vojni označuje v 50. letih 20. st. najprej razcvet ustanavljanja meteoroloških postaj, kasneje pa njihovo zmanjševanje. Vseskozi je na razpolago več postaj s padavinskimi podatki, manj s temperaturnimi. Problem je, da postaje niso delovale nepretrgoma, zato so potrebne interpolacije manjkajočih podatkov. Od leta 1951 naprej so za Park Škocjanske jame na razpolago padavinski podatki. Padavinske pojave so najprej od januarja 1951 do decembra 1993 nepretrgoma merili in opazovali v Matavunu (n. v. 426 m). Interpolirane so le vrednosti za leto 1976, ko postaja ni delovala (Klimatografija Slovenije. Padavine 1951-1980, 1989, str. 38; Klimatografija Slovenije. Količina padavin ..., 1995, str. 158). Od septembra 2005 naprej meritve opravljajo v Škocjanu (n. v. 420 m) (Arhiv meteoroloških podatkov ARSO, 2013). Za vmesno 
obdobje podatkov ni. Za potrebe te analize smo niz podatkov o višini padavin izpopolnili s pomočjo interpoliranih vrednosti, pri čemer smo si pomagali s podatki za okoli $7 \mathrm{~km}$ oddaljeno Kozino, ki ima zelo podobne padavinske značilnosti (preglednica 4). V preglednici 4 so dodane še vrednosti za Godnje pri Tomaju in Ilirsko Bistrico, ki imajo tudi zelo sorodne padavinske značilnosti.

Preglednica 4: Povprečna mesečna in letna višina padavin (v mm) za Matavun (n. v. 426 m), Kozino (n. v. 490 m), Ilirsko Bistrico (n. v. 414 m) in Godnje pri Tomaju (n. v. 295 m) za obdobje 1961-1990

Table 4: Average monthly and annual precipitation (in $\mathrm{mm}$ ) at Matavun (426 m), Kozina (490 m), Ilirska Bistrica (414 m) and Godnje near Tomaj (295 m) in the 1961-1990 period

\begin{tabular}{|l|l|l|l|l|l|l|l|l|l|l|l|l|l|}
\cline { 2 - 27 } \multicolumn{1}{c|}{} & Jan. & Feb. & Mar. & Apr. & Maj & Jun. & Jul. & Avg. & Sep. & Okt. & Nov. & Dec. & Leto \\
\hline Matavun & 104 & 89 & 106 & 117 & 119 & 144 & 99 & 125 & 141 & 132 & 153 & 120 & 1449 \\
\hline Kozina & 113 & 96 & 113 & 128 & 122 & 146 & 101 & 130 & 144 & 133 & 163 & 123 & 1511 \\
\hline II. Bistrica & 106 & 92 & 112 & 111 & 112 & 129 & 97 & 120 & 133 & 146 & 172 & 118 & 1447 \\
\hline Godnje & 108 & 88 & 107 & 110 & 114 & 135 & 96 & 123 & 131 & 134 & 154 & 115 & 1417 \\
\hline
\end{tabular}

Vir/Source: Klimatografija Slovenije. Količina padavin ..., 1995, str. 57, 78, 113 in 158

S pomočjo predvojnega niza podatkov za Škocjan smo za Matavun interpolirali tudi padavinske vrednosti za standardno meteorološko obdobje 1931-1960 (preglednica 5). Za primerjavo dodajamo še podatke za Ilirsko Bistrico, Kozino in Sežano za isto obdobje.

Preglednica 5: Povprečna mesečna in letna višina padavin (v mm) na meteoroloških postajah Matavun (n. v. 426 m), Ilirska Bistrica (n. v. 420 m), Kozina (n. v. 490 m) in Sežana (n. v. $380 \mathrm{~m})$ v obdobju 1931-1960

Table 5: Average monthly and annual precipitation (in $\mathrm{mm}$ ) at the meteorological stations of Matavun (426 m), Ilirska Bistrica (420 m), Kozina $(490 \mathrm{~m})$ and Sežana $(380 \mathrm{~m})$ in the 1931-1960 period

\begin{tabular}{|l|l|l|l|l|l|l|l|l|l|l|l|l|l|}
\cline { 2 - 14 } \multicolumn{1}{c|}{} & Jan. & Feb. & Mar. & Apr. & Maj & Jun. & Jul. & Avg. & Sep. & Okt. & Nov. & Dec. & Leto \\
\hline Matavun & 103 & 81 & 88 & 89 & 129 & 146 & 109 & 99 & 147 & 149 & 158 & 112 & 1410 \\
\hline Il. Bistrica & 109 & 101 & 94 & 89 & 123 & 115 & 100 & 84 & 146 & 163 & 185 & 127 & 1436 \\
\hline Kozina & 104 & 83 & 80 & 96 & 97 & 149 & 109 & 93 & 102 & 145 & 172 & 112 & 1354 \\
\hline Sežana & 94 & 83 & 73 & 81 & 114 & 121 & 92 & 85 & 138 & 134 & 136 & 186 & 1257 \\
\hline
\end{tabular}

Vir/Source: Pučnik, 1980, str. 308-311

V prvih desetletjih po 2. svetovni vojni so temperaturo zraka v jugovzhodnem delu Krasa med januarjem 1948 in marcem 1961 merili na Kozini (n. v. 490 m) (Povše, 1984). Meritve iz tega časa so bile tudi interpolirane na drugo standardno klimatološko obdobje 1931-1960 (preglednica 6). Od januarja 1954 do septembra 2000 obstaja kontinuiran niz temperaturnih podatkov za Ilirsko Bistrico (n. v. 414 m). Meritve v Ilirski Bistrici so se začele z oktobrom 1954, zato so vrednosti za prvih devet mesecev tega leta interpolirane. Kljub podobni nadmorski višini podatkov za Ilirsko Bistrico nismo uporabili za analizo temperaturne 
spremenljivosti po 2. svetovni vojni na jugovzhodu Krasa, ker se niz zaključi z letom 1999 (Arhiv meteoroloških podatkov ARSO, 2013), ampak podatke za nekoliko nižje ležeče Godnje pri Tomaju (n. v. 295 m). Postaja ni ves čas delovala na istem mestu, ima tudi nekaj izpada meritev. Interpolirane so vrednosti za januarske temperature leta 1956 in 1958 ter podatki za zimo 1989/90 (Klimatografija Slovenije. Temperatura zraka za obdobje 1961-1990, 1995, str. 42), podatke za prve štiri mesece leta 1992 pa smo interpolirali s pomočjo podatkov za Ilirsko Bistrico z metodo ohranjanja razlik med postajama. V Godnjah pri Tomaju so z meritvami pričeli leta 1956, leta 1992 so postajo iz dna podolja prestavili proti severovzhodu v okoli 140 m oddaljen in 20 m višje ležeči zaselek, ki spada pod Tomaj. Primerjava povprečnih temperatur časovnega niza za čas pred selitvijo in po njej z referenčno postajo Bilje je pokazala, da je Tomaj nekoliko toplejši od Godenj zaradi bolj zatišne in prisojne lege nad dnom podolja: pri povprečnih letnih in spomladanskih temperaturah za $0,2{ }^{\circ} \mathrm{C}$, pri jesenskih za $0,3{ }^{\circ} \mathrm{C}$ in zimskih za $0,6^{\circ} \mathrm{C}$. Povprečni poletni temperaturi se med lokacijama ne razlikujeta (Brezovnik, 2004). Zaradi tega smo niz podatkov po preselitvi postaje ustrezno korigirali in dobili bolj homogeni niz za obravnavano obdobje 1956-2011.

Slika 2: Meteorološka postaja Godnje pri Tomaju (foto: D. Ogrin)

Figure 2: Meteorological station at Godnje near Tomaj (photo: D. Ogrin)

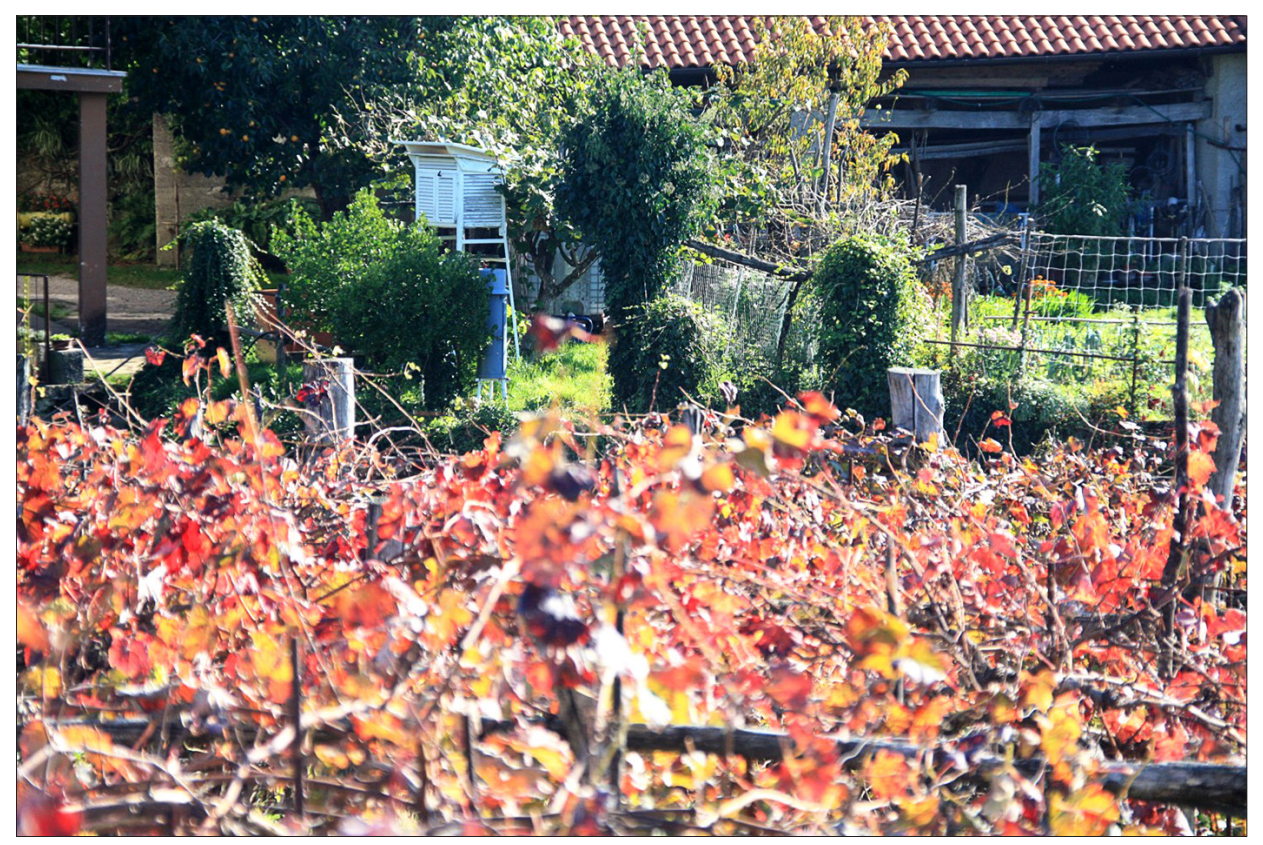

Za primerjavo, kakšne so razlike v povprečnih temperaturah zraka na širšem obravnavanem območju, so v preglednici 6 zbrani podatki za Ilirsko Bistrico, Kozino in Šmarje pri Sežani, ki so iz krajših nizov meritev preračunani na obdobje 1931-1960, v preglednici 7 pa podatki za Godnje pri Tomaju in Ilirsko Bistrico v obdobju 1961-1990. 
Preglednica 6: Povprečna mesečna in letna temperatura zraka $\left(v^{\circ} \mathrm{C}\right)$ na meteoroloških postajah Ilirska Bistrica (n .v. 414 m), Kozina (n. v. 490 m) in Šmarje pri Sežani (n. v. 311 m) v obdobju 1931-1960

Table 6: Average monthly and annual air temperatures $\left(\right.$ in $\left.{ }^{\circ} \mathrm{C}\right)$ at the meteorological stations of Ilirska Bistrica (414 m), Kozina (490 m) and Šmarje pri Sežani $(311 \mathrm{~m})$ in the 1931-1960 period

\begin{tabular}{|l|l|l|l|l|l|l|l|l|l|l|l|l|l|}
\cline { 2 - 13 } \multicolumn{1}{c|}{} & Jan. & Feb. & Mar. & Apr. & Maj & Jun. & Jul. & Avg. & Sep. & Okt. & Nov. & Dec. & Leto \\
\hline Kozina & 0,2 & 1,6 & 4,6 & 8,8 & 13,2 & 16,9 & 19,0 & 18,6 & 15,2 & 10,2 & 5,4 & 2,1 & 9,6 \\
\hline II. Bistrica & 0,2 & 1,9 & 5,3 & 9,9 & 13,2 & 16,9 & 18,5 & 17,9 & 14,6 & 9,5 & 5,3 & 1,6 & 9,6 \\
\hline Šmarje & 1,7 & 3,1 & 6,3 & 10,5 & 14,5 & 18,2 & 20,2 & 20,1 & 16,8 & 11,9 & 7,3 & 3,7 & 11,2 \\
\hline
\end{tabular}

Vir/Source: Pučnik, 1980, str. 306-307

Preglednica 7: Povprečna mesečna in letna temperatura zraka $\left(v^{\circ} \mathrm{C}\right)$ na meteoroloških postajah Godnje pri Tomaju (n. v. 295 m) in Ilirska Bistrica (n. v. 414 m) v obdobju 1961-1990

Table 7: Average monthly and annual air temperatures $\left(\right.$ in $\left.{ }^{\circ} \mathrm{C}\right)$ at the meteorological stations of Godnje near Tomaj (295 m) and Ilirska Bistrica (414 m) in the 1961-1990 period

\begin{tabular}{|l|l|l|l|l|l|l|l|l|l|l|l|l|l|}
\cline { 2 - 13 } \multicolumn{1}{c|}{} & Jan. & Feb. & Mar. & Apr. & Maj & Jun. & Jul. & Avg. & Sep. & Okt. & Nov. & Dec. & Leto \\
\hline Godnje & 1,6 & 2,7 & 5,7 & 9,8 & 14,3 & 17,6 & 19,8 & 19,3 & 15,8 & 11,2 & 6,3 & 2,7 & 10,6 \\
\hline Il. Bistrica & 0,8 & 2,1 & 5,0 & 8,9 & 13,2 & 16,4 & 18,7 & 18,0 & 14,7 & 10,2 & 5,6 & 1,7 & 9,6 \\
\hline
\end{tabular}

Vir/Source: Klimatografija Slovenije. Temperatura zraka: obdobje 1961-1990, 1995, str. 42, 48

\section{TEMPERATURNI IN PADAVINSKITRENDI ZA METEO- ROLOŠKI POSTAJI GODNJE PRI TOMAJU IN MATAVUN (PARK ŠKOCJANSKE JAME) PO 2. SVETOVNIVOJNI}

Za Slovenijo na splošno velja, da se je v obdobju 1951-2000 povprečna temperatura zraka statistično značilno povečala za $1,1 \pm 0,6{ }^{\circ} \mathrm{C}$. Najbolj se je dvignila v urbaniziranih okoljih (Maribor $1,7 \pm 0,6^{\circ} \mathrm{C} / 50$ let, Ljubljana $1,4 \pm 0,6^{\circ} \mathrm{C} / 50$ let) in $v$ gorskem svetu (Kredarica $1,2 \pm 0,6^{\circ} \mathrm{C} / 47$ let), manj pa v manj in neurbaniziranih okoljih ter ob morju $\left(0,6-0,8 \pm 0,6^{\circ} \mathrm{C} / 50\right.$ let). Ogrevanje je najizrazitejše pozimi in spomladi, kar se npr. kaže v zmanjšanju števila dni s snežno odejo in zgodnejšem nastopu fenoloških faz rastlin (Bergant in sod., 2004; Podnebne razmere v Sloveniji, 2006). Zelo izrazit trend ogrevanja je v zadnjih treh desetletjih. Za obdobje 1979-2008 znaša za Slovenijo, preračunan na 100 let, kar okoli $6{ }^{\circ} \mathrm{C}$, kar daleč presega svetovno povprečje (Dolinar, Vertačnik, 2010, str. 38). Študije kažejo, da se spomladanske razvojne faze pri rastlinah (cvetenje, olistanje drevja) v zadnjih desetletjih začnejo 6 do 10 dni prej kakor v 50 . letih 20. st. (Črepinšek, Zrnec, 2005).

Zaradi naraščanja temperature se po vsej Sloveniji, še najmanj v Obsredozemskih pokrajinah, povečuje število toplih in vročih dni, zmanjšuje pa število hladnih in ledenih dni. Število toplih dni, ko najvišje dnevne temperature presežejo $25^{\circ} \mathrm{C}$, se je v obdobju 
1950-2009 povečevalo s stopnjo od 2,2 (Novo mesto) do 4,8 dni (Postojna) na desetletje. V Ljubljani, kjer je potrebno upoštevati tudi učinek mestnega podnebja, se je število vročih dni (najvišje dnevne temperature nad $30^{\circ} \mathrm{C}$ ) v obdobju 1991-2000 v primerjavi z obdobjem 1961-1970 povečalo za več kot $200 \%$ (Vysoudil, Jurek, 2005). Ledenih dni, ko tudi najvišje dnevne temperature ne presežejo $0{ }^{\circ} \mathrm{C}$, pa je bilo od 2,7 (Rateče) do 5,2 dneva (Novo mesto) na desetletje manj. Tropske noči (najnižje nočne temperature nad $20{ }^{\circ} \mathrm{C}$ ), ki so bile z izjemo obalnega pasu Slovenske Istre v notranjosti Slovenije redek pojav, so postale v nekaterih mestih v notranjosti Slovenije že vsakoleten pojav (Bertalanič in sod., 2010, str. 4). Opazno je tudi zmanjševanje števila dni z meglo in podaljševanje trajanja Sončevega obsevanja.

Letna količina padavin v obdobju 1971-2005 ne kaže enotnega vzorca spreminjanja. Ta ponekod statistično značilno narašča, drugod se zmanjšuje, veliko je tudi merilnih mest, kjer trend ni statistično značilen. Očitno pa je, da se praktično po vsej državi povečuje jesenska količina padavin in da se, razen v visokogorju, zmanjšujejo poletne padavine. Naraščanje zimskih temperatur in manj padavin pozimi vpliva tudi na sneg in snežno odejo. Za Slovenijo je značilno, da se po 2. svetovni vojni višina novozapadlega snega znižuje s stopnjo od 2 (Murska Sobota) do $22 \mathrm{~cm}$ (Rateče) na desetletje, število dni s snežno odejo v sezoni pa od 2 do 4 dni na desetletje (Bertalanič in sod., 2010, str. 4).

Preglednica 8: Spremenljivost temperature zraka v Godnjah pri Tomaju v obdobju 1956-2011 $\left(v^{\circ} \mathrm{C}\right)$

Table 8: Changeability of air temperatures at Godnje near Tomaj in the 1956-2011 period (in ${ }^{\circ} \mathrm{C}$ )

\begin{tabular}{|c|c|c|c|c|c|c|c|}
\hline & Povp. & \begin{tabular}{|l|} 
Stand. \\
odklon
\end{tabular} & $\begin{array}{l}\text { Najnižja } \\
\text { temp. }\end{array}$ & $\begin{array}{c}\text { Najvišja } \\
\text { temp. }\end{array}$ & $\begin{array}{c}\text { Trend } \\
\left({ }^{\circ} \mathrm{C} / 50 \text { let }\right)\end{array}$ & $\begin{array}{l}\text { Najtoplejši letni } \\
\text { čas/leto }\end{array}$ & $\begin{array}{l}\text { Najhladnejši letni } \\
\text { čas/leto }\end{array}$ \\
\hline Pomlad & 10,3 & 1,0 & $\begin{array}{c}8,1 \\
(1987)\end{array}$ & $\begin{array}{c}13,5 \\
(2007)\end{array}$ & $+1,4$ & $\begin{array}{l}2007(13,5), 2009 \\
(12,5), 2011(12,2), \\
2001(12,0)\end{array}$ & $\begin{array}{l}1963(-0,7), 1964 \\
(0,6), 1981(0,6), 1985 \\
(0,9)\end{array}$ \\
\hline Poletje & 19,6 & 1,1 & $\begin{array}{c}17,7 \\
(1984)\end{array}$ & $\begin{array}{c}23,9 \\
(2003)\end{array}$ & $+2,2$ & $\begin{array}{l}2003(23,9), 1994 \\
(21,4), 2009(21,0), \\
2011(21,0)\end{array}$ & $\begin{array}{l}1984(17,7), 1978 \\
(17,9), 1965(18,1), \\
1960(18,2)\end{array}$ \\
\hline Jesen & 11,4 & 0,8 & $\begin{array}{c}9,7 \\
(1972)\end{array}$ & $\begin{array}{c}13,7 \\
(2006)\end{array}$ & $+0,6$ & $\begin{array}{l}2006(13,7), 2000 \\
(13,3), 2009(12,9), \\
2011(12,8)\end{array}$ & $\begin{array}{l}1972(9,7), 1978(9,8), \\
1974(9,9), 1971(9,9)\end{array}$ \\
\hline Zima & 2,6 & 1,1 & $\begin{array}{c}-0,7 \\
(1963)\end{array}$ & $\begin{array}{c}5,8 \\
(2007)\end{array}$ & $+0,4$ & $\begin{array}{l}2007(5,8), 2001(5,3), \\
1998(5,1), 1994(4,4)\end{array}$ & $\begin{array}{l}1963(-0,7), 1964 \\
(0,6), 1981(0,6), 1985 \\
(0,9)\end{array}$ \\
\hline Leto & 11,0 & 0,7 & $\begin{array}{c}9,8 \\
(1980)\end{array}$ & $\begin{array}{c}12,7 \\
(2007)\end{array}$ & $+1,2$ & $\begin{array}{l}2007(12,7), 1994 \\
(12,4), 2001(12,4), \\
2003(12,4)\end{array}$ & $\begin{array}{l}1980(9,8), 1956(9,9), \\
1965(9,9), 1978(9,9)\end{array}$ \\
\hline
\end{tabular}

Izračunano iz/Calculated from: Arhiv meteoroloških podatkov ARSO, 2013; Klimatografija Slovenije. Temperaturne razmere za območje SR Slovenije v obdobju 1951-1980, 1988, str. 31; Klimatografija Slovenije. Temperatura zraka: obdobje 1961-1990, 1995, str. 42 


\section{I. Spreminjanje in trendi sezonskih in letnih temperatur zraka $v$ Godnjah pri Tomaju v obdobju I956-20I I}

Kakor velja na splošno za Slovenijo, kaže tudi analiza podatkov za Godnje pri Tomaju na dvig temperature zraka po 2. svetovni vojni. Povprečna letna temperatura zraka se je dvignila s trendom $1,2^{\circ} \mathrm{C} / 50$ let, kar je pomembna sprememba, saj presega standardni odklon (preglednica 8). Toplejši kakor v začetku meritev so bili vsi letni časi, najbolj so se segrela poletja (trend $+2,2{ }^{\circ} \mathrm{C} / 50$ let) in pomladi, najmanj pa zime (trend $+0,4{ }^{\circ} \mathrm{C} / 50$ let) in jeseni (sliki 3 in 4). V Trstu so po podatkih za obdobje 1955-2009 tendence spreminjanja temperature zraka podobne, le da so trendi zaradi večje maritimnosti manj izraziti. Poletja so se ogrevala s trendom $1,4{ }^{\circ} \mathrm{C} / 50$ let, povprečne letne temperature pa s stopnjo $0,9^{\circ} \mathrm{C} / 50$ let. Manjše so razlike $\mathrm{v}$ trendih $\mathrm{v}$ hladni polovici leta.

Slika 3: Spreminjanje povprečnih letnih temperatur v Godnjah pri Tomaju v obdobju 1956$2011\left(v^{\circ} \mathrm{C}\right)$

Figure 3: Changes in average annual temperatures at Godnje near Tomaj in the 1956-2011 period $\left(\right.$ in $\left.^{\circ} \mathrm{C}\right)$

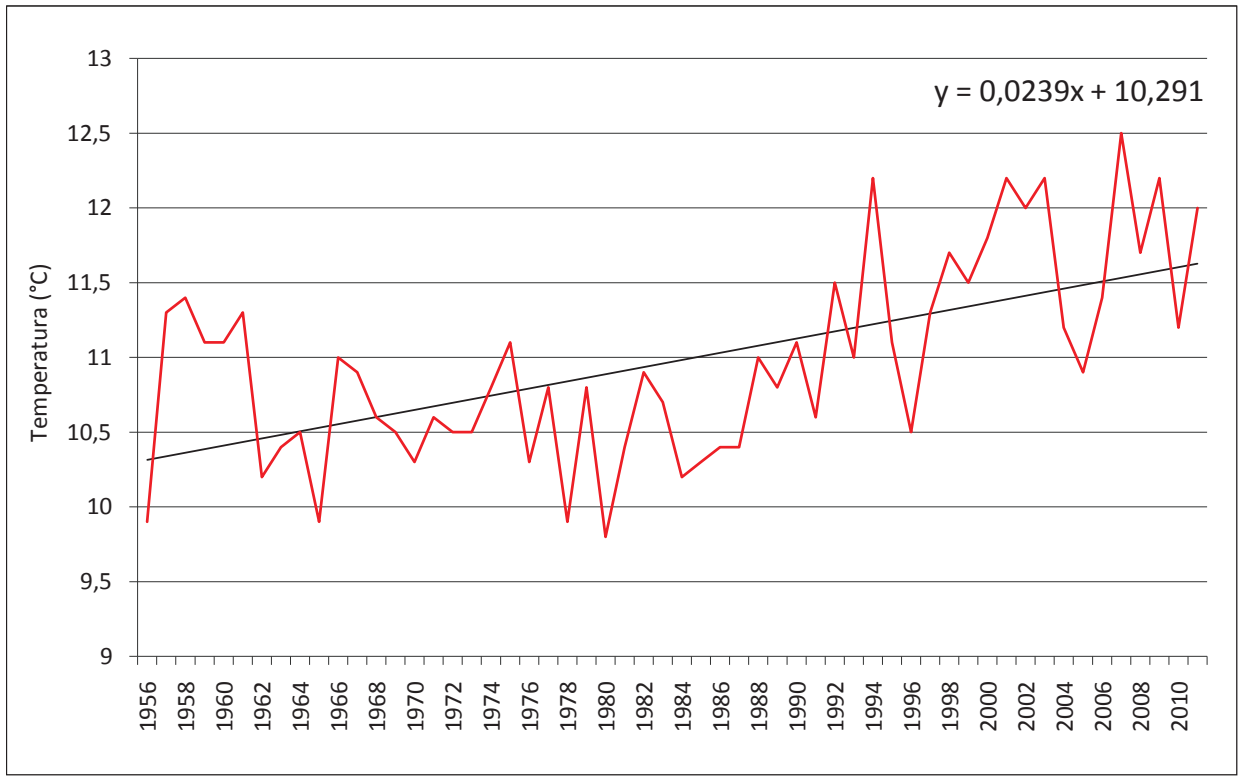


Slika 4: Spreminjanje povprečnih poletnih temperatur v Godnjah pri Tomaju v obdobju 1956$2011\left(v^{\circ} \mathrm{C}\right)$

Figure 4: Changes in summer temperatures at Godnje near Tomaj in the 1956-2011 period (in ${ }^{\circ} \mathrm{C}$ )

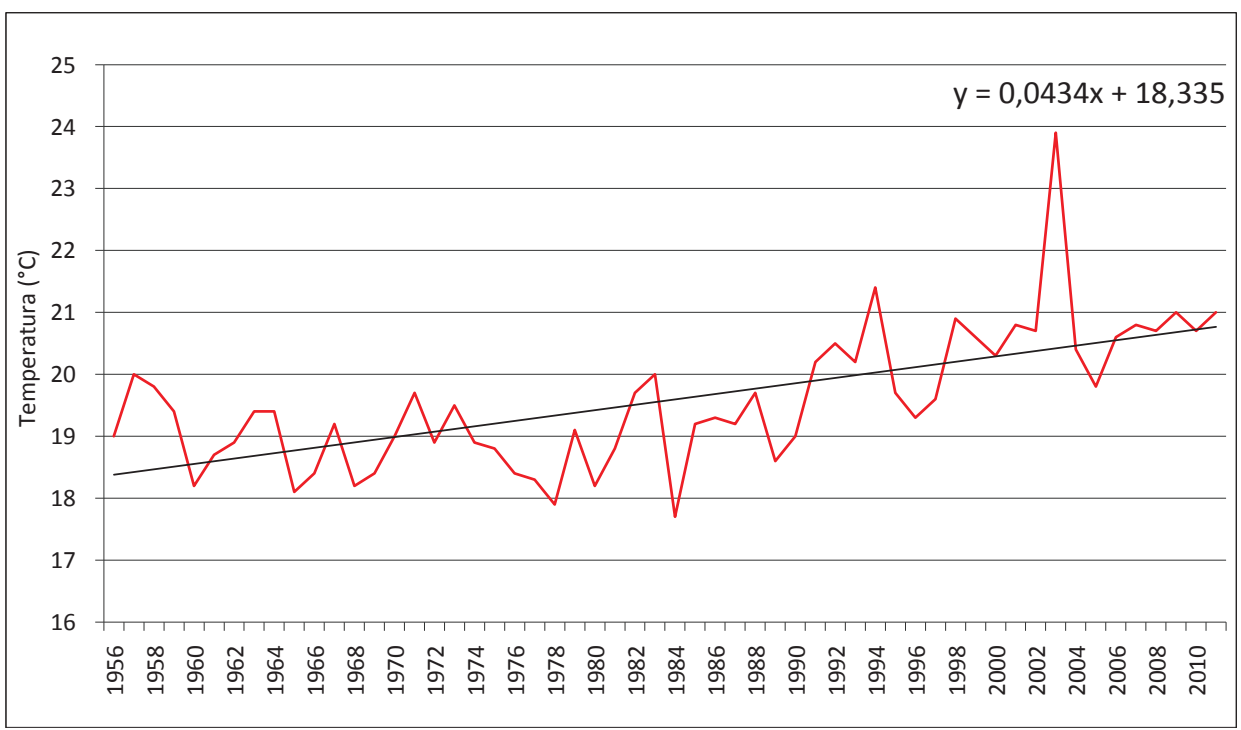

Do 80 . let 20. st. so se sezonske temperature večinoma gibale okoli dolgoletnega povprečja, oziroma so bila le krajša obdobja z nad- ali podpovprečnimi temperaturami. Sredi oziroma ob koncu 80. letih pa so se začele temperature intenzivno dvigovati. Pri povprečnih letnih temperaturah je podobno, le da so si nadpovprečno topla leta sledila tudi v začetku meritev do začetka 60. let 20. st. Na bistveno toplejši zadnji dve desetletji kažejo desetletna povprečja (preglednica 9), kakor tudi razvrstitev najtoplejših oziroma najhladnejših letnih časov oziroma let (preglednica 8). Praviloma so se najtoplejši letni časi in leta zvrstili v zadnjih dveh desetletjih, še zlasti v zadnjem, najhladnejši pa v prvih 25 letih meritev.

Preglednica 9: Godnje pri Tomaju-desetletna temperaturna povprečja $\left(v^{\circ} \mathrm{C}\right)$

Table 9: Godnje near Tomaj - ten-year temperature averages $\left(\right.$ in $\left.{ }^{\circ} \mathrm{C}\right)$

\begin{tabular}{|l|c|c|c|c|c|}
\hline Desetletje & Zima & Pomlad & Poletje & Jesen & Leto \\
\hline $\mathbf{1 9 6 1 - 1 9 7 0}$ & 1,9 & 9,9 & 18,8 & 11,7 & 10,6 \\
\hline $\mathbf{1 9 7 1 - 1 9 8 0}$ & 3,0 & 9,8 & 18,8 & 10,5 & 10,5 \\
\hline $\mathbf{1 9 8 1 - 1 9 9 0}$ & 2,1 & 10,0 & 19,1 & 11,4 & 10,7 \\
\hline $\mathbf{1 9 9 1 - 2 0 0 0}$ & 2,8 & 10,6 & 20,3 & 11,5 & 11,3 \\
\hline $\mathbf{2 0 0 1 - 2 0 1 0}$ & 2,9 & 11,2 & 20,9 & 11,8 & 11,7 \\
\hline
\end{tabular}

Izračunano iz /Calculated from: Arhiv meteoroloških podatkov ARSO, 2013; Klimatografija Slovenije. Temperaturne razmere za območje SR Slovenije v obdobju 1951-1980, 1988, str. 31; Klimatografija Slovenije. Temperatura zraka: obdobje 1961-1990, 1995, str. 42 


\subsection{Spreminjanje in trendi sezonskih in letnih padavin v Matavunu v obdobju I 95 I-20I I}

Nizov za ugotavljanje padavinske spremenljivosti po 2. svetovni vojni je več kakor temperaturnih, kjer smo imeli za jugovzhodni del Krasa na razpolago le podatke za Godnje pri Tomaju. Na razpolago so podatki za Godnje pri Tomaju, Sežano, Kozino in Matavun (Škocjan), vendar nobena od naštetih padavinskih postaj nima popolnega niza za celotno obdobje. Zaradi reprezentativnosti, dolžine niza in zadovoljive kvalitete podatkov sosednjih postaj v primerih, ko je bilo potrebno podatke interpolirati, smo za analizo trendov izbrali Matavun.

V primerjavi s temperaturo zraka so padavine bistveno bolj spremenljive, tako glede količine padavin, padavinskega režima, kakor tudi trendov v posameznih obdobjih. Pri sezonskih in letnih vsotah znaša povprečna spremenljivost 20 do $30 \%$, pri mesečnih pa je lahko dolgoletno povprečje preseženo za več kot $100 \%$ ali pa pade minimalna količina, in to ne glede na letni čas. Padavinski režim je v celotni južni, jugozahodni in zahodni Sloveniji zmerno sredozemski, s primarnim viškom v jeseni (november, oktober) in sekundarnim na prehodu pomladi v poletje, običajno junija. Najbolj sušen je običajno prehod zime v pomlad (februar, marec), sekundarni minimum pa je julija in avgusta.

Letna količina padavin se je v Matavunu v obdobju 1951-2011 postopno zmanjševala. Trend je značilen in znaša $-341 \mathrm{~mm} / 50$ let. Postopno so se zmanjševale padavine v vseh letnih časih, še najbolj poleti (trend $-108 \mathrm{~mm} / 50$ let). Trendi za spomladanske, jesenske in zimske padavine niso statistično značilni, saj ne presegajo standardnega odklona. V primerjavi z večino meteoroloških postaj v Sloveniji in tudi s Trstom, na katerih se padavine v jeseni povečujejo, za Matavun to ne velja. V Matavunu tudi jesenske padavine kažejo rahlo tendenco zmanjševanja (preglednica 10). Zmanjševanje količine padavin v vseh letnih časih, še posebej v topli polovici leta, ob hkratnem naraščanju temperature zraka, vodi v večjo sušno ogroženost.

Preglednica 10: Spremenljivost padavin v Matavunu v obdobju 1951-2011 (v mm) Table 10: Changeability of precipitation at Matavun in the 1951-2011 period (in mm)

\begin{tabular}{|l|c|c|c|c|c|l|l|}
\cline { 2 - 8 } \multicolumn{1}{l|}{} & Povp. & $\begin{array}{c}\text { Stand. } \\
\text { odklon }\end{array}$ & $\begin{array}{c}\text { Najnižja } \\
\text { višina pad. }\end{array}$ & $\begin{array}{c}\text { Najvišja } \\
\text { višina pad. }\end{array}$ & $\begin{array}{c}\text { Trend: } \\
\text { mm/100 let }\end{array}$ & $\begin{array}{l}\text { Najbolj namočen } \\
\text { letni čas/leto }\end{array}$ & $\begin{array}{l}\text { Najbolj suh } \\
\text { letni čas/leto }\end{array}$ \\
\hline Pomlad & 312 & 93 & $115(2003)$ & $558(1975)$ & -80 & $\begin{array}{l}1975,1970, \\
1978,1962\end{array}$ & $\begin{array}{l}2003,1973, \\
1993,1997\end{array}$ \\
\hline Poletje & 353 & 106 & $92(2003)$ & $628(1963)$ & $-\mathbf{1 0 8}$ & $\begin{array}{l}1963,1977, \\
1965,1960\end{array}$ & $\begin{array}{l}2003,2001, \\
1971,1951\end{array}$ \\
\hline Jesen & 422 & 157 & $125(2006)$ & $853(1960)$ & -55 & $\begin{array}{l}1960,1993, \\
2010,1992\end{array}$ & $\begin{array}{l}2006,1957, \\
1988,1983\end{array}$ \\
\hline Zima & 303 & 131 & $92(1989)$ & $693(1977)$ & -82 & 1977,1979, & 1989,1992, \\
1960,2010 & 1975,1993 \\
\hline Leto & 1391 & 249 & $836(2003)$ & $2050(1960)$ & $-\mathbf{3 4 1}$ & $\begin{array}{l}1960,1965, \\
1952,1963\end{array}$ & $\begin{array}{l}2003,2011, \\
1971,1999\end{array}$ \\
\hline
\end{tabular}

Izračunano iz/Calculated from: Arhiv meteoroloških podatkov ARSO, 2013; Klimatografija Slovenije. Količina padavin: obdobje 1961-1990, 1995, str. 158; Klimatografija Slovenije. Padavine 1951-1980, 1989, str. 38 
Slika 5: Spreminjanje poletne višine padavin (v mm) v Matavunu v obdobju 1951-2011

Figure 5: Changes in summer precipitation amounts (in mm) at Matavun in the 1951-2011 period

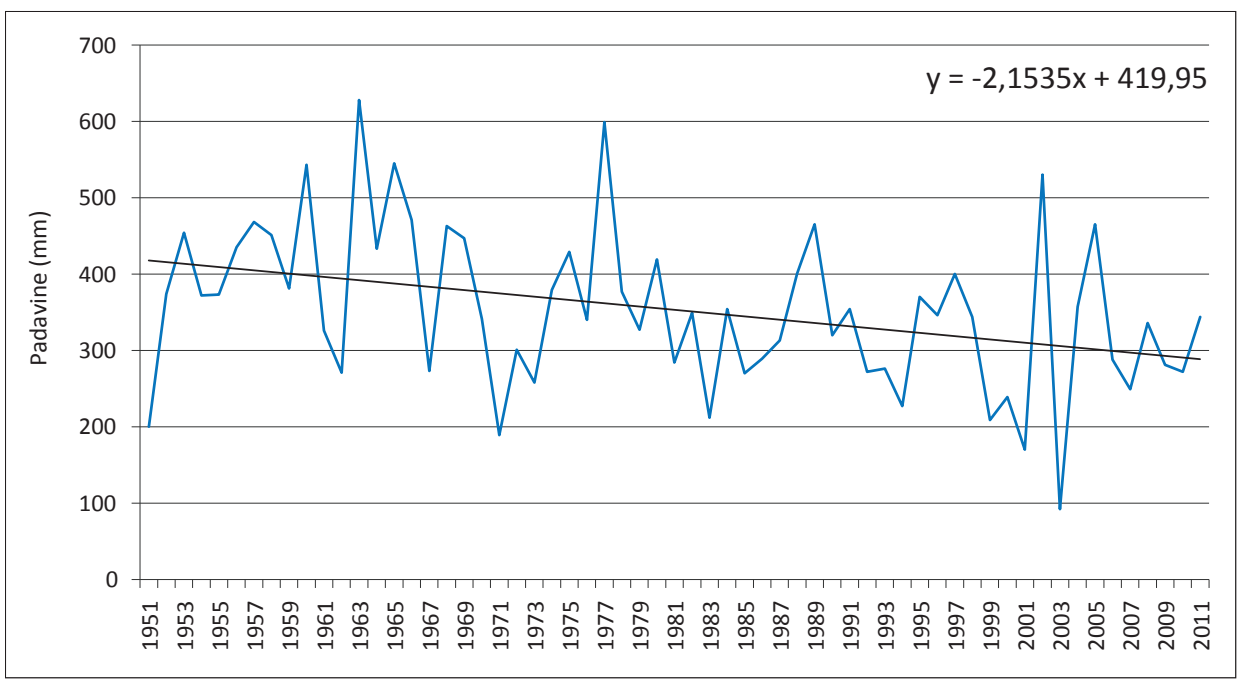

Slika 6: Spreminjanje letne višine padavin (v mm) v Matavunu v obdobju 1951-2011

Figure 6: Changes in annual precipitation amounts (in mm) at Matavun in the 1951-2011 period

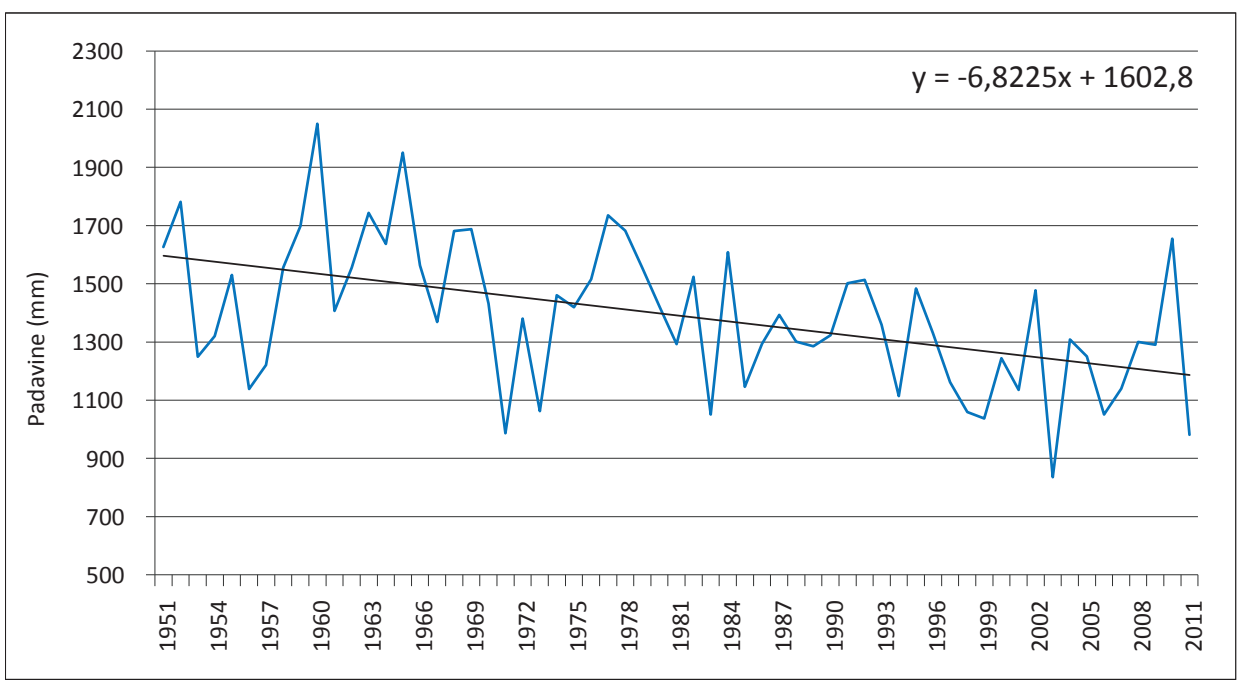

Podobno kot za temperature v Godnjah pri Tomaju tudi za padavine v Matavunu na splošno velja, da so bile, z izjemo posameznih let, od srede 80. let 20. st. večinoma pod dolgoletnim povprečjem. V zadnjih 25 letih (z izjemo leta 2014) tako ne najdemo leta, ki bi se uvrstilo med najbolj namočene, imamo pa kar tri, ki izstopajo po zelo majhni 
količini padavin. Med njimi je bilo najbolj suho leta 2003, ko je padlo $60 \%$ običajne količine padavin. Le nekoliko bolj izdatno s padavinami je bilo leto 2011. Podobno je tudi pri pomladih in poletjih. Najbolj namočene pomladi in poletja so se zvrstile v prvih tridesetih letih meritev do leta 1980, najbolj suhe, z nekaj izjemami, pa po letu 1980. Jesenski in zimski ekstremi so razporejeni po celotnem obdobju.

Tendenca postopnega zmanjševanja količine padavin je razvidna tudi iz primerjave desetletnih povprečij (preglednica 11). V zadnjih dveh desetletjih so se zimske, pomladne in poletne padavine $\mathrm{v}$ primerjavi s prvima dvema desetletjema zmanjšale za $12-16 \%$, letne pa za $19 \%$. Jesenske padavine so ostale na približno isti ravni, s tendenco rahlega zmanjševanja. Negativni trend jesenskih padavin za celotno obdobje je predvsem posledica manj namočenih jeseni v četrtem desetletju obravnavanega obdobja, to je med leti 1981 in 1990, in nadpovprečnih v desetletju 1961-1970.

Preglednica 11: Matavun - desetletna padavinska povprečja (v mm)

Table 11: Matavun - ten-year precipitation averages (in $\mathrm{mm}$ )

\begin{tabular}{|l|c|c|c|c|c|}
\hline Desetletje & Zima & Pomlad & Poletje & Jesen & Leto \\
\hline $\mathbf{1 9 5 1 - 1 9 6 0}$ & 360 & 320 & 404 & 419 & 1517 \\
\hline $\mathbf{1 9 6 1 - 1 9 7 0}$ & 335 & 371 & 420 & 485 & 1602 \\
\hline $\mathbf{1 9 7 1 - 1 9 8 0}$ & 319 & 328 & 362 & 415 & 1422 \\
\hline $\mathbf{1 9 8 1 - 1 9 9 0}$ & 294 & 328 & 326 & 374 & 1322 \\
\hline $\mathbf{1 9 9 1 - 2 0 0 0}$ & 223 & 270 & 304 & 472 & 1280 \\
\hline $\mathbf{2 0 0 1 - 2 0 1 0}$ & 296 & 267 & 304 & 384 & 1244 \\
\hline
\end{tabular}

Izračunano iz/Calculated from: Arhiv meteoroloških podatkov ARSO, 2013; Klimatografija Slovenije. Količina padavin, obdobje 1961-1990, 1995, str. 158; Klimatografija Slovenije. Padavine 1951-1980, 1989, str. 38

\subsection{Tendence spreminjanja podnebja $v$ obdobju $I 99 I-20 I 0 \mathrm{v}$ primer- javi z obdobjem I 96 I-1990}

Smer spreminjanja podnebja v zadnjih dveh desetletjih v primerjavi s standardnim klimatološkim obdobjem 1961-1990, s hkratnim upoštevanjem mesečnih, sezonskih in letnih temperatur in padavin, smo ugotavljali za meteorološko postajo Godnje pri Tomaju. Že iz primerjave desetletnih povprečij (preglednici 9 in 10) je razvidno, da sta bili zadnji dve desetletji v povprečju bistveno toplejši in nekoliko manj namočeni kot velja za obdobje 1961-1990. Najbolj so se ogreli poletni meseci, med njimi avgust (za 1,7 $\left.{ }^{\circ} \mathrm{C}\right)$. Ostali letni časi in leta kot celota so bili toplejši za okoli $1^{\circ} \mathrm{C}$. Hladna polovica leta (oktober-marec) se je nekoliko manj ogrela kot topla polovica. Tudi za zadnji dve desetletji velja, da se je zaledje Tržaškega zaliva bolj intenzivno ogrevalo od obalnih predelov, kjer so bili letni časi (in leta) toplejši za okoli $0,5^{\circ} \mathrm{C}$ od predhodnega obdobja. Za razliko od zaledja pa so se ob obali manj segrele pomladi in jeseni.

Če so trendi segrevanja v jugovzhodnih delih Krasa v zadnjih dveh desetletjih pomembni, pa za spreminjanje padavin, ki so bolj variabilne, tega ne moremo trditi. Opazna 
je sicer tendenca zniževanja letne količine padavin in padavin v obdobju od januarja do vključno avgusta, ki pa ni značilna. Najbolj so se padavine zmanjšale ob koncu zime in v začetku pomladi, od 20 do $25 \%$. V poletnih mesecih jih je bilo okoli $10 \%$ manj, najbolj izrazito so se zmanjšale junija (14 \%), kar je pomembno z vidika poletnih zalog vode. V primerjavi z negativnim trendom za obdobje 1951-2011 so se jesenske padavine v zadnjih dveh desetletjih nekoliko povečale. Od septembra do decembra je v obdobju 1991-2010 padlo od 13-19 \% več padavin kot v obdobju 1961-1990. V primerjavi s Trstom, kjer so se najbolj okrepile padavine v oktobru, so se v zaledju Tržaškega zaliva, najbolj povečale septembrske padavine; to kažejo tudi podatki za Bilje.

Postopno višanje temperatur vseh letnih časov, trajanja Sončevega obsevanja in zmanjševanje količine padavin, $\mathrm{z}$ istočasno krepitvijo jesenskih padavin, napeljujejo na tezo, da so se v zadnjih dveh desetletjih ob Tržaškem zalivu in v njegovem zaledju krepile sredozemske podnebne poteze. Zime, pomladi in poletja so postajali vedno bolj topli in suhi, jeseni pa toplejše in bolj vlažne. Leta kot celota pa so bila toplejša, brez pomembnejše spremembe letne vsote padavin (slika 7).

Slika 7: Odklon temperature zraka $\left(v^{\circ} \mathrm{C}\right)$ in padavin (v\%) v obdobju 1991-2010 od povprečja standardnega klimatološkega obdobja 1961-1990 za meteorološke postaje z zmerno sredozemskim podnebjem

Figure 7: Deviation of air temperature $\left(\right.$ in ${ }^{\circ} \mathrm{C}$ ) and precipitation (in \%) in the 1991-2010 period from the average of the 1961-1990 standard climatological period at meteorological stations with sub-Mediterranean climate

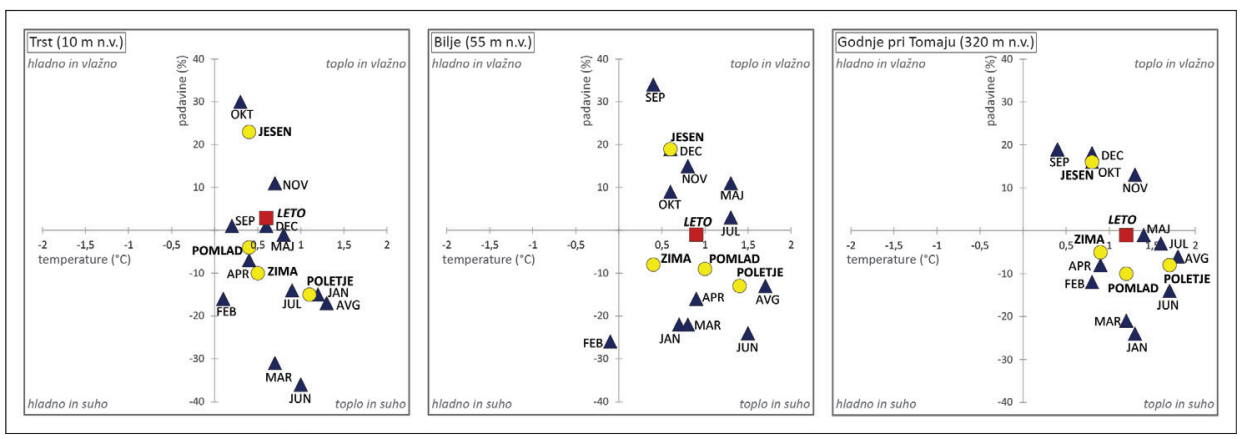

\section{SKLEP}

Pri obravnavi tendenc spreminjanja podnebja v predelih Slovenije z zmerno sredozemskim podnebjem najpogosteje analiziramo podatke meteoroloških postaj neposredno ob obali Tržaškega zaliva (Portorož, Trst) in Bilj, ki sicer ležijo v zaledju Tržaškega zaliva, vendar imajo nizko nadmorsko višino $(55 \mathrm{~m})$ in precejšen maritimen vpliv. Zaradi tega so podnebne razmere Bilj in z njimi povezani trendi spreminjanja podnebja v zadnjih desetletjih podobni kot ob morju. Spregledani pa so višje ležeči predeli z zalednim zmerno sredozemskim podnebjem (jugovzhodni Kras, Brkini, dolina Reke), kjer se zmerno 
sredozemske podnebne poteze bolj prepletajo s celinskimi. Zaradi tega smo predpostavljali, da so tudi trendi spreminjanja podnebja nekoliko drugačni kot ob morju. Težava pri ugotavljanju podnebne spremenljivosti teh pokrajin je pomanjkanje meteoroloških postaj, kratki nizi podatkov, prestavljanje meteoroloških postaj in vprašljiva homogenost podatkovnih nizov, kljub izvedenim interpolacijam in homogenizacijam. To še posebej velja za temperaturne meritve. Za ugotavljanje tendenc spreminjanja podnebja po 2 . svetovni vojni $\mathrm{v}$ jugovzhodnih delih Krasa sta se izkazali kot najprimernejši meteorološki postaji Godnje pri Tomaju in Matavun (Škocjan, Park Škocjanske jame).

Domneva, da so nekatere poteze spreminjanja podnebja v višje ležečih in bolj v notranjost pomaknjenih predelih Obsredozemskih pokrajin z zalednim zmerno sredozemskim podnebjem drugačne kot $\mathrm{v}$ obalnih predelih, se je izkazala za pravilno. Zaledje izkazuje višjo stopnjo segrevanja ozračja kot kraji ob morju, še posebej v topli polovici leta. Trenda za spomladanske in poletne temperature sta tako bolj podobna trendom v nižjih predelih osrednje Slovenije kakor pa trendom ob obali Tržaškega zaliva. V zaledju se je količina padavin zmanjševala $v$ vseh letnih časih, najbolj poleti. Pomembno raven zmanjšanja sta dosegli poletna in letna vsota padavin. Ob morju je bilo padavin po letu 1951 tudi vse manj, razen v jeseni, ko so se rahlo povečale, vendar so trendi neznačilni. Povečevanje jesenskih padavin (in zmanjševanje $\mathrm{v}$ ostalih letnih časih) je značilnost večine padavinskih postaj v Sloveniji, zaradi česar se krepijo zmerno sredozemske poteze padavinskega režima. V zadnjih dveh desetletjih je jesenskih padavin vse več tudi v Matavunu. Negativen

Slika 8: Kras v okolici Škocjanskih jam (foto: D. Ogrin)

Figure 8: Kras near Škocjanske jame caves (photo: D. Ogrin)

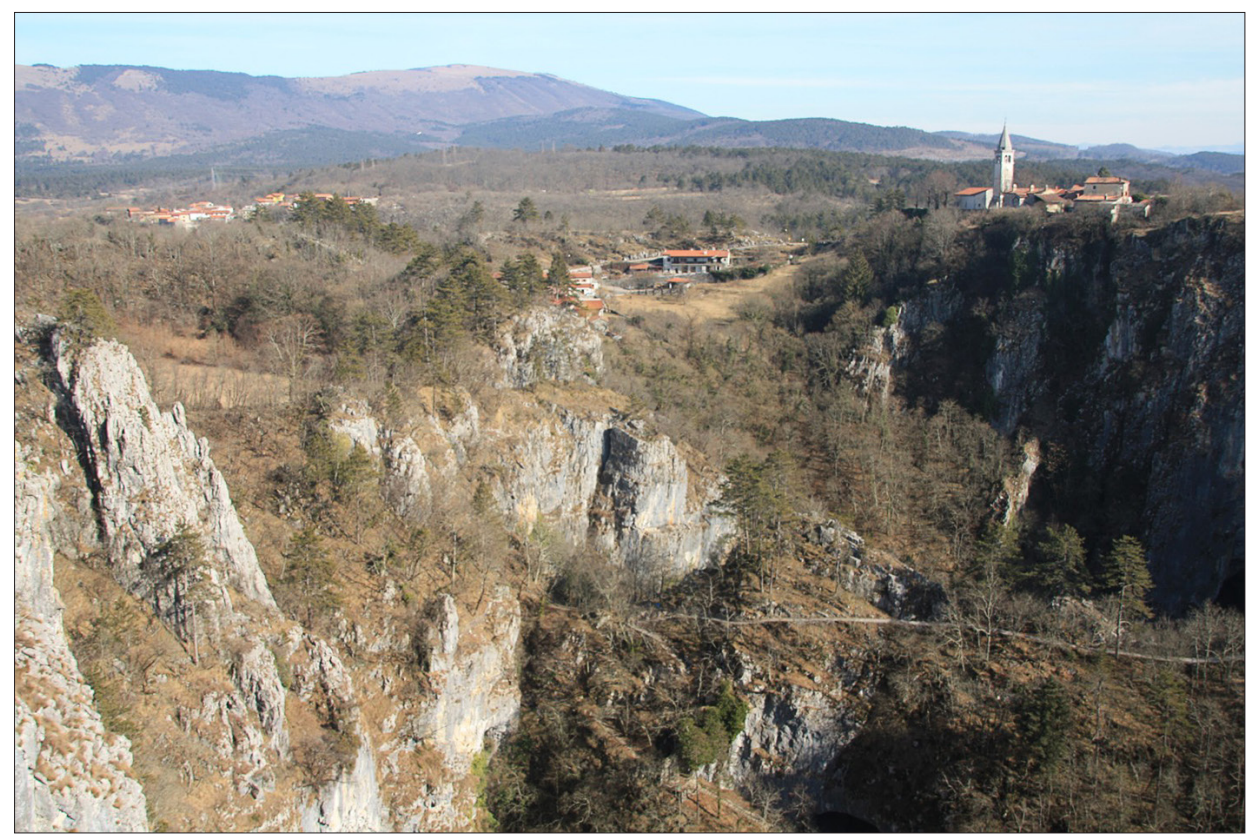


trend za celotno obdobje je predvsem posledica izrazito nadpovprečno namočenih jeseni konec 50. in v začetku 60. let 20. st. Za ponazoritev: jeseni leta 1960 je v Matavunu padlo kar 853 mm padavin (202 \% povprečne vsote za jesen). Če primerjamo zadnji dve desetletji s standardnim klimatološkim obdobjem 1961-1990 lahko sklenemo, da tudi podnebje v višje ležečih pokrajinah obsredozemske Slovenije postaja vse toplejše, še posebej spomladi in poleti, ter bolj sušno. Le jeseni postajajo toplejše in bolj vlažne. V zaledju je segrevanje ozračja v topli polovici leta in zmanjševanje letne vsote padavin izrazitejše kot ob obali, povečanje jesenskih padavin pa manj izrazito.

\section{Viri in literatura}

Arhiv meteoroloških podatkov. 2013. Ljubljana, ARSO, Državna meteorološka služba. URL: http: meteo.arso.gov.si/met/sl/archive (Citirano 15. 1. 2013).

Beltram, G., Kranjc, A., Kranjc, D., Mihevc, A., Peric, B., Slapnik, R., Turk, P., Zorman, T., Zupanc Hrastar, S., 2012. Park Škocjanske jame. Škocjan, Park Škocjanske jame, 121 str.

Benussi, B., 1903. Manuale di geografia, storia e statistica della regione Giulia (littorale) ossia della città immediata di Trieste, della contea principesca di Gorizia e Gradisca e del Margraviato d'Istria. Poreč, 360 str.

Bergant, K., 2007. Projekcije podnebnih sprememb za Slovenijo. V: Jurc, M. (ur.). Podnebne spremembe - vpliv na gozd in gozdarstvo. Studia forestalia Slovenica, 130, str. 67-86.

Bergant, K., Kajfež Bogataj, L., Sušnik, A., Cegnar, T., Črepinšek, Z., Kurnik, B., Dolinar, M., Gregorič, G., Rogelj, D., Žust, A., Matajc, I., Zupančič, B., Pečenko, A., 2004. Spremembe podnebja in kmetijstvo v Sloveniji. Ljubljana, ARSO, 40 str.

Bertalanič, R., Demšar, M., Dolinar, M., Dvoršek, D., Nadbath, M., Pavčič, B., Roethel-Kovač, M., Vertačnik, G., Vičar, Z., 2010. Spremenljivost podnebja v Sloveniji. Ljubljana, ARSO, 11 str. URL: http://meteo.arso.gov.si/uploads/probase/www/climate/text/sl/publications/spremenljivost\%20podnebja.pdf (Citirano 26. 9. 2014).

Biel, E., 1927. Klimatographie des ehemaligen österreichischen Küstenlandes. Wien, Hölder-Pichler-Tempsky A. G., 59 str.

Brezovnik, U., 2004. Vpliv spremembe lokacije klimatološke postaje na meritve temperature zraka (na izbranih primerih). Diplomsko delo. Ljubljana, Filozofska fakulteta, Oddelek za geografijo, 98 str.

Črepinšek, Z., Zrnec, C., 2005. Petinpetdeset let fenoloških opazovanj v Sloveniji, 19512005. Acta agriculturae Slovenica, 85, 2, str. 283-297. URL: http://aas.bf.uni-lj.si/ oktober2005/11 crepinsek2.pdf (Citirano 26. 9. 2014).

Dolinar, M., Vertačnik, G., 2010. Spremenljivost temperaturnih in padavinskih razmer v Sloveniji. V: Cegnar, T. (ur.). Okolje se spreminja - Podnebna spremenljivost Slovenije in njen vpliv na vodno okolje. Ljubljana, ARSO, str. 37-40. URL: http://www. arso.gov.si/o\%20agenciji/knji\%C5\%BEnica/publikacije/Okolje_se\%20spreminja. pdf (Citirano 26. 9. 2014).

Gams, I., 1998. Geomorphogenetics of the classical Karst - Kras. Acta carsologica, 27, 2, str. 181-198. URL: http://carsologica.zrc-sazu.si/downloads/272/gams.pdf (Citirano 26. 9. 2014). 
Gams, I., Kogovšek, J., 1998. The dynamics of flowstone deposition in the caves Postojnska, Planinska, Taborska and Škocjanske, Slovenia. Acta carsologica, 27, 1, str. 299-324.

Kajfež Bogataj, L., Pogačar, T., Ceglar, A., Črepinšek, Z., 2010. Spremembe agro-klimatskih spremenljivk v Sloveniji v zadnjih desetletjih. Acta agriculturae Slovenica, 95, 1, str. 97-109. URL: http://aas.bf.uni-lj.si/februar2010/13kajfez.pdf (Citirano 2. 10. 2014).

Klimatografija Slovenije. Količina padavin: obdobje 1961-1990. 1995. Ljubljana, Hidrometeorološki zavod Republike Slovenije, 366 str.

Klimatografija Slovenije. Padavine 1951-1980. 1989. Ljubljana, Hidrometeorološki zavod SR Slovenije, 393 str.

Klimatografija Slovenije. Temperaturne razmere na območju SR Slovenije v obdobju 1951-1980. 1988. Ljubljana, Hidrometeorološki zavod SR Slovenije, 331 str.

Klimatografija Slovenije. Temperatura zraka: obdobje 1961-1990. 1995. Ljubljana, Hidrometeorološki zavod Republike Slovenije, 356 str.

Krš Slovenije. 1957. Bura, D. (ur.). Split, Savezno savetovanje o kršu, 275 str.

Mazelle, E., 1908. Klimatographie des österreichischen Küstenlandes. A: Triest. Wien, $71 \mathrm{str}$.

Mihevc, A., 1995. Geomorphological meaning of the sediments beneath the entrance potholes in the area of Škocjanske jame - the case of Jama na Prevali II. V: Bella, P. (ur.). Caves and man. International symposium on the occasion of the 70th anniversary opening to the public of the Demänovská cave of Liberty. Liptovský Mikuláš, Slovak Museum of Nature Protection and Speleology, str. 16-20.

Mihevc, A., 1999. Unroofed caves, cave sediments and karst surface geomorphology case study from Kras, W Slovenia. Naš krš, 19, 32, str. 3-11.

Mihevc, A. 2001. Speleogeneza Divaškega krasa (Zbirka ZRC, 27). Ljubljana, Založba ZRC, 180 str.

Mihevc, A., 2002. Klima, geologija in geomorfologija. V: Peric, B. (ur.). Park Škocjanske jame, Škocjan, Park Škocjanske jame, str. 58-65.

Mihevc, A., Stepišnik, U., 2011. Uporaba metode električne upornosti tal na primeru Divaške jame. Dela, 35, str. 45-54. DOI: 10.4312/dela.35.3.45-54

Mrak, I., Repe, B., 2000. Physical geographic conditions for vine growth in the Karst region, Slovenia. Acta geographica Croatica, 35, 1, str. 67-96. URL: http://hrcak.srce. $\mathrm{hr}$ /index.php?show=clanak\&id_clanak_jezik=123638 (Citirano 2. 10. 2014).

Mrak, I., Repe, B., 2004. Vine and the vine growing in the area of Kras (Slovenia). Geoadria, 9, 2, str. 223-242. URL: http://hrcak.srce.hr/file/14793 (Citirano 2. 10. 2014).

Ogrin, D., 1994. Modern age climatic fluctuations in the area of the Gulf of Trieste. Geografski zbornik, 34, str. 5-80. URL: http://giam.zrc-sazu.si/zbornik/GZ_3401_005080.pdf (Citirano 2. 10. 2014).

Ogrin, D., 1995. Podnebje Slovenske Istre (Knjižnica Annales, 11). Koper, Zgodovinsko društvo za južno Primorsko, 381 str.

Ogrin, D., 1996. Podnebni tipi v Sloveniji. Geografski vestnik, 68, str. 39-56. URL: http://www.dlib.si/?URN=URN:NBN:SI:DOC-NDDCHX2Y (Citirano 2. 10. 2014). 
Ogrin, D., 2003. Spreminjanje temperature zraka in padavin po letnih časih v Ljubljani in Trstu v obdobju 1851-2002. Dela, 20, str. 101-114. DOI: 10.4312/dela.20.11.115-131 Ogrin, D., 2000. Prispevek k poznavanju fizičnogeografske podobe Sečoveljskih solin. Annales, Series historia naturalis, 10, 2, str. 253-262.

Ogrin, D., 2012. Spreminjanje podnebja ob Tržaškem zalivu in projekcije za 21. stoletje. V: Ogrin, D. (ur.). Geografija stika Slovenske Istre in Tržaškega zaliva (Zbirka GeograFF, 12). Ljubljana, Znanstvena založba Filozofske fakultete, str. 87-105.

Ogrin, D., Plut, D., 2009. Aplikativna fizična geografija Slovenije. Ljubljana, Znanstvena založba Filozofske fakultete, 246 str.

Podnebne razmere v Sloveniji (obdobje 1971-2000). 2006. Ljubljana, ARSO, 27 str. URL: http://www.arso.gov.si/vreme/podnebje/podnebne_razmere_slo71_00.pdf (Citirano 15. 3. 2012).

Povše, M., 1984. Imenik ali seznam krajev z vremenskimi postajami v SR Sloveniji in kronološkim pregledom dosedanjih meteoroloških opazovanj. Elaborat. Ljubljana, Hidrometeorološki zavod SR Slovenije, 107 str.

Prilozi poznavanju klime Jugoslavije. 2. Padavine u Jugoslaviji: rezultati osmatranja za period 1925-1940. 1957. Beograd. Hidrometeorološka služba FNR Jugoslavije, 571 str.

Pučnik, J., 1980. Velika knjiga o vremenu. Ljubljana, Cankarjeva založba, 367 str.

Stepišnik, U., 2008. The application of electrical resistivity imaging in collapse doline floors: Divača karst, Slovenia. Studia Geomorphologica Carpatho-Balcanica, 42, str. 41-56.

Stepišnik, U., Černuta, L., Ferk, M., Gostinčar, P., 2007. Reliktni vršaji kontaktnega krasa severozahodnega dela Matarskega podolja. Dela, 28, str. 29-42. DOI: 10.4312/ dela.28.3.29-42

Stepišnik, U., Ferk, M., Kodelja, B., Burger, B., Abramović, M., Peterca, S., 2009. Brezstropa jama v Podbojevem lazu, Rakov Škocjan. Dela, 31, str. 37-53. DOI: 10.4312/ dela.31.3.37-53

Stravisi, F., 1976. Considerazioni statistiche sui valori medi mensili di cinque elementi meteorologici, Trieste 1841-1975. Trieste (Trst), Istituto Sperimentale Talassografico F. Vercelli, Publicazione No. 529, str. 1-53.

Vysoudil, M., Jurek, M., 2005. Summer air temperatures in Ljubljana (Slovenia) and Olomouc (Czech Republic) in the period 1961-2000. Dela, 23, str. 245-257. DOI: $10.4312 /$ dela.23.7.245-257 


\section{CLIMATE CHANGE TENDENCIES AFTER THE SECOND WORLD WAR IN THE SOUTHEASTERN KRAS}

\section{Summary}

The southeastern part of the Kras, between Dutovlje and the Caves of Škocjan, lies at the altitude of 300 to $450 \mathrm{~m}$ and is more intensely closed with a chain of hills towards the sea than its lower-lying northwestern part, where climate conditions are closer to those on the shore of the Gulf of Trieste. Due to the higher altitude and a more continental position, the sub-Mediterranean climate features are combined with the continental ones. Hence it was presumed that the trends in climate changing in the southeastern part of the Kras in the last decade were slightly different from those by the sea. There are no meteorological stations in the discussed area that have worked uninterruptedly and provided a homogenous series of data. Through the interpolation and homogenization of data by the neighbouring meteorological stations, we completed the temperature and the precipitation series for Godnje near Tomaj (295 m) and Matavun (the Škocjan Caves Landscape Park, $426 \mathrm{~m}$ ) for the 1951-2011 period. Analyzed were the seasonal and the annual values.

As is generally the case in Slovenia, the series of data for Godnje near Tomaj also shows the rising of air temperatures after the Second World War. The average annual air temperature rose at the rate of 1.2 degrees $/ 50$ years, which is a typical change. All seasons were warmer than at the beginning of measurements; the highest rise is manifest in summer (trend +2.2 degrees $/ 50$ years) and spring, the lowest in winter (trend +0.4 degrees $/ 50$ years) and autumn. The tendencies in air temperature changes along the coast of the Gulf of Trieste were similar, but the trends were less explicit because of the more intense maritime features. The annual precipitation amount at Matavun in the 1951-2011 period gradually declined. The trend is typical and amounts to $-341 \mathrm{~mm} / 50$ years. In all seasons, precipitations gradually declined, most evidently in summer (trend $-180 \mathrm{~mm} / 50$ years), but the trends are not statistically significant.

If the last two decades are compared to the standard 1961-1990 climatological period, it can be concluded that also in the 1991-2010 period the climate warmed intensely and tended to be dryer in general, which further enhanced the threat of drought. Autumn months are exception to this, since they became warmer and wetter. In the higher southeastern part of the Kras, air warming in the warm half of the year was more explicit whereas the increase in autumn precipitation was smaller than by the sea. The gradual increase in temperatures in all the seasons, the decline of precipitation amounts, and the concurrent intensification of autumn precipitation indicate that during the last two decades the Mediterranean climate features intensified both along the Gulf of Trieste and in its hinterland. Winters, springs and summers were becoming ever warmer and dryer, while autumns were warmer and wetter.

(Translated by Branka Klemenc) 